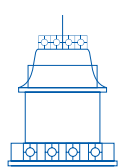

ARTÍCULOS

DE INVESTIGACIÓN

\title{
Capital par excellence: on money as an obscure thing*
}

\author{
Werner Bonefeld \\ University of York, York, Inglaterra \\ E-mail: werner.bonefeld@york.ac.uk \\ Recibido: 5 de noviembre de 2019 | Aprobado: 19 de febrero de 2020 \\ https://doi.org/10.17533/udea.ef.n62a03
}

\begin{abstract}
Against the background of the contemporary debate about financialisation, the paper conceptualises the capitalist labour economy as fundamentally a monetary system. It argues that money is not a capitalist means of organising its labour economy but that it is rather a capitalist end. The argument examines and finds wanting conceptions of money in political economy, including Keynesianism and neoliberalism, and argues that the debate about financialisation is fundamentally based on the propositions of political economy. It holds that Marx's critique of political economy conceives of money as the form of value and expounds money-making as the purpose of the capital labour economy. Thus, the labour theory of value is fundamentally a monetary theory of value, labour is the means of valorisation, and that is, of money in process, and as such capital. Making money out of money is capital as its most rational. In the form of credit, money posits wealth as a claim on future surplus value.
\end{abstract}

Keywords: capital, money, financialisation, debt, labour economy, surplus value, crisis

* This paper is an output of the project "Ordoliberalism and the Crisis of Neoliberal Political Economy" funded by ECONOMIC AND SOCIAL RESEARCHCOUNCIL (ESRC), United Kingdom. Iam gratefultoChrisO'Kane, Chris Arthurand SantiagoArango Muñozfortheircareful reading. Thanks are due also for the two anonymous referees for their helpful advice and guidance.

Cómo citar este artículo:

Bonefeld, W. (2020). Capital Par Excellence: On Money as an obscure thing. Estudios de Filosofía, 62, 33-56. https://doi.org/10.17533/udea.ef.n62a03 


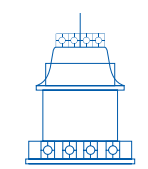

ARTÍCULOS

DE INVESTIGACIÓN

\section{Capital par excellence: el dinero como una cosa oscura}

Resumen: En el contexto del debate contemporáneo sobre la financiarización, el artículo conceptualiza la economía del trabajo capitalista como un sistema fundamentalmente monetario. Se sostiene que el dinero no es un medio capitalista para organizar su economía del trabajo, sino que es más bien un fin capitalista. El argumento examina críticamente concepciones deficientes del dinero en la economía política, como el keynesianismo y el neoliberalismo, y afirma que el debate sobre la finaciarización se basa fundamentalmente en las proposiciones de la economía política. El artículo sostiene que la crítica de Marx a la economía política concibe el dinero como la forma de valor y la generación del dinero como el propósito de la economía del trabajo de capital. Así, la teoría del valor-trabajo es fundamentalmente una teoría monetaria del valor, el trabajo es el medio de valorización, es decir, del dinero en proceso y, como tal, del capital. Hacer dinero con dinero es el capital en su forma más racional. En forma de crédito, el dinero presenta la riqueza como una demanda sobre la plusvalía futura.

Palabras clave: capital, dinero, financiarización, deuda, economía laboral, plusvalía, crisis

\section{Werner Bonefeld}

Professor of Politics, University of York (UK). Recent book publications have included The Strong State and the Free Economy (2017), Critical Theory and the Critique of Political Economy (2014/2016), Notes from Tomorrow (2015), and as co-editor The Sage Handbook of Frankfurt School Critical Theory, 3 volumes (2018). Recent journal articles in the area of Marxism, Critical Theory and German neoliberalism have appeared in Critical Sociology, Science \& Society, History of the Human Sciences and Capital \& Class. 
The title of this contribution derives from characterisations used by Marx to specify what is now called finance capital. He deems it to be an 'obscure thing', a Dunkelding (Marx, 1976, p. 447). He characterised it as such because it asserts itself as the source of its own self-expansion (M....M'). In the form of money that yields more money, 'capital assumes an independent form' (Marx, 1966, p. 382), from which 'the relation to labour' is seemingly eliminated (Marx, 1976, p. 456). Seemingly it accumulates wealth in the 'undifferentiated homogeneous form of independent value - money' (Marx, 1966, p. 368). Marx calls it capital par excellence (Marx, 1976, p. 447) because, as the source of its own self-expansion, it posits wealth 'without content' (Marx, 1966, p. 392), and conceives of it as a 'pure fetish form' (p. 393). He uses the word 'bewitching' to characterise its ability to lay golden eggs (Marx, 1990, ch. 4). When dealing with credit-relations in Capital volume III, he expounds on this characterisation arguing that finance capital is 'the meaningless [begriffslose] form of capital, the perversion and objectification of production relations in their highest degree, the interest-bearing form, the simple form of capital, in which it antecedes its own process of reproduction' (Marx, 1966, p. 392).' What does it mean to say that finance capital is an 'automatic fetish' (p. 392) and what is the source of its social power?

What Marx conceives of in critical terms, developing a critical theory of capitalist society as the objectification of the "money subject" (Marx, 1973, p. 144), contemporary analysis conceives of as a new form of capitalism, which is characterised as financial capitalism (Lapavitsas, 2012; Sawyer, 2018). This new capitalist form is said to generate wealth through monetary operations alone, including financial gaming and debt bondage. Crucially, the argument about its emergence is premised on the notion that money making has become an end in itself. Fundamentally, the transformation of productive capitalism into financial capitalism is characterised by the transformation of money from a means of capitalist economy into a capitalist end. It is argued that capitalism became a monetary system because of the financialisation of the economy that started in the early 1980 s with the implementation of the so-called neoliberal class project (Harvey, 2004). In contrast, this paper argues that capitalism is fundamentally a monetary system. ${ }^{2}$ The "wealth of societies in which the capitalist mode of production prevails" manifests itself in the "dazzling money-form" (Marx, 1990, pp. 125 and 139). I hold that capitalism is not "merely a system in which money is used. It is a monetary system". In capitalism "money forms the centre of the social universe" (Smith, 2005, p. 174-75). It

1 In the English version begriffslos is translated as 'meaningless'. Marx does not treat the money subject as meaningless, far from it. Begriffs/os is difficult to translate and 'meaningless' is not a bad attempt if it is understood in the sense of 'losing its grip, lacking in grasp or hold' in that 'the money subject' loses its hold on the valorisation of labour as the living means of the money form.

2 One external reviewer commented that there is a tension between the conception of capitalism as a monetary system and the earlier point about finance capital as an automatic fetish. The comprehension of these formulations rests on the understanding of the meaning of fetishism. The capitalist social relations assume the form of a relationship between things that manifests itself behind the backs of individuals who endow their reified world with a consciousness and a will through their actions. What asserts itself behind their backs is their own world in the form of the economic object. The money system is the automatic subject. Fetishism is real. 
entails a dynamic that "leads to a universal subordination of (potentially) everything to the money form" (Lotz, 2014, p. 32), including the mortgaging of the future through an accumulation of potentially fictitious promissory notes on future surplus value.

I argue that money is the independent form of value. ${ }^{3}$ It is not paper, neither gold nor silver. In fact, money does not represent the value of commodities. Rather it presents it to them. It is a real social abstraction that appears in the form of the money subject. ${ }^{4}$ The freedom of the money subject is the freedom of monetization. In this freedom the needs of the social individuals are a mere metaphysical distraction to the calculation of economic quantities. Although the privileges of the few and the wants of the many are determined by their possession of money, everybody is compelled to work for money as more money. Working for profit as an end in itself is the inescapable condition of maintaining capital value on the part of the capitalists and of securing sustained access to the means of subsistence on the part of the working class.

The following section introduces classical conceptions of money as a means of labour economy. It establishes the understanding of money in economic theory, including, briefly, its Marxist variant. Then follows a section about money as the form of value. It expounds a monetary theory of value. There then follows a section on value, labour and money time. It explores the concept of socially necessary labour time as the time of money. The final section addresses Marx's characterisation of financial capital as begriffslos. It argues that credit money entails a gamble on the future valorisation of living labour, which is experienced as debt bondage.

\section{Money as means}

The economists have almost nothing to say about the (begriffslose) power of money. ${ }^{5}$ For them, money is simply a convenient instrument that makes multilateral exchange much simpler. According to classical political economy "[m]oney is what money does". It acts "as a unit of account (...), as a means of payment, and as a store of value", which developed over time into "ever more sophisticated ways of reducing transaction costs" (Hicks,

3 This conception is fundamental to the value form analysis pioneered first by Backhaus (1997) and Reichelt (2008), and then by Arthur (2002), Heinrich (2017), Pitts (2018) and Bonefeld (2014). See also Clarke (1988; 1992). Value form analysis conceives of Marx's critique of political economic as a critical social theory.

4 One referee recommended that the argument presented here should expound the autonomist Marxist argument that money is a capitalist tool of command. The understanding of money as a tool of capitalist command and the critique of money as the form of value, belong to different theoretical worlds. The one presumes that value is an economic category, which since the collapse of the Bretton Woods system in the early 1970s has been supplanted by money as a means of capitalist power, the other conceives of money as a (reified) form of social relations. On the autonomist conception of money, see Negri (1984) and Cleaver (1995).

5 For an insightful account, see Clarke (1988), upon which a great deal of the following argument rests. I refer to 'the economists' as a generic term to depict a disciplinary effort at determining the meaning of the economic categories in abstraction from their social foundation. On this, see Bonefeld (2014). 
1967, pp. 1 and 7). It is deemed to be a rational means through which the hidden hand of the market manifests itself, telling the market participants what to sell and where to invest. For Adam Smith, men do not desire money for its own sake. Rather they desire money "for the sake of what they can purchase with it" (Smith, 1976, p. 385). He identifies productive labour as the source of social wealth in what he terms "commercial society". He views money as mediating the exchange relations between individual producers. As such it functions as a means of social interaction and as an instrument of economic organisation. It is not an end in itself. For Smith, to treat it as an end, to desire it for its own sake, expresses a mercantilist prejudice. In commercial society, "consumption is the sole end and purpose of all production" (p. 155). Money enables consumption by facilitating the processes of selling and buying in a rational manner (C...M...C). ${ }^{6}$ The limitations of money to function in this straightforward manner have nothing to do with money as a means of wealth. They are a social phenomenon brought about by human ignorance, selfishness and greed. It is human greed which disrupts the rationality of money. Smith thus writes about the greed of the merchants, the self-interest of the masters, the ignorance of the workers, the indolence of the landed class, and one might add, the avarice of the money dealers. Instead of using coins to sell and to buy, they are clipped, in one way or another, hindering the progress of the wealth of nations through leakages in the circular flow of money, of buying and selling. ${ }^{7}$ In short, in the classical tradition associated with the work of Smith and also of Ricardo, labour produces the wealth of nations and wealth represents labour. Money is the means of facilitating the exchange between those who, say, expended labour to produce firewood and those who expended it to produce shoes. ${ }^{8}$ The world of Smith is a world of (simple) commodity production and exchange relations, in which money is a rational instrument of commerce.

David Ricardo conceives of money as a standard of value. He developed a labour theory of value according to which the substance of the value of a commodity is the quantity of labour embodied in it. According to Ricardo money is the standard through which this substance is expressed in the form of price. As the standard of value Ricardian money compares and measures the labour quantity of various products in the act of market-exchange. In order for money to operate as the measure of commodity-value, its standard has to be both invariable and neutral. According to Ricardo for as long as the value of money is "invariable (...) all alterations in price [express] some alteration in the value of the commodity" (1951, p. 46). Ricardian money is effectively "labour time money". It is held to be denominated labour time and is conceived of as a neutral measure of the embodied value substances.

6 C...M....C describes the process of simple commodity circulation - a Commodity (C) is exchanged for Money (M) which is then exchange for another Commodity (C). Money functions as a means of the selling and buying of commodities.

7 On clipped coins, see Caffentzis (1989). On the leakages in the circular flow of money, and how to fix it, see Keynes (2017).

8 This is the example used by Driffill and Stiglitz (2000, p. 24) in their account of money as a cunning device of the capitalist economic organisation. 
John Maynard Keynes (2017) does not conceive of money primarily as a means of exchange. He conceived of it as money of account, which entails a conception of money as credit-money that is created by the state and the banking system. In contrast to the classical tradition, in the credit-system money is not a neutral economic means. Rather, it is an economic end. Banks trade money as a commodity with the expectation that it generates a profit in the form of interest. For Keynes, credit-money derives from the existence of ignorance and uncertainty, which make it rational to withdraw money from circulation and to hold it instead as an interest-bearing property or speculative asset. The thrust of his argument is that, for the sake of the real economy, credit money has to be regulated by the state and become state-money, which is used by public authority to effect the performance of the (real) economy. This endeavour entails the curtailment of money as an end in itself, containing the rational irrationality of money making so that it may function as symbol of value to sustain real economic growth. Contrary to money making, public authority uses money to secure the secular flow of income to support the relations of buying and selling in the real economy and to secure the availability of investment credit. In explanation, the limits of accumulation appear in the form of available money. This limitation is overcome by access to credit, which is provided by banks on the promise of interest payment. This deal is founded on the expectation that the borrower maintains economic activity and returns to profit. However, although credit-sustained accumulation suspends the barriers to accumulation by keeping the borrowers afloat, it further feeds the overaccumulation of capital and accelerates inflation. At some point, and whatever triggers the crash, credit contracts, and the credit-structure finds itself on the brink as credit transforms into worthless debt. At the same as the demand for cash increases to avoid default, the banks themselves are on the brink as bad debt becomes a noose around their neck.

Central to the idea of Keynes's General Theory (2017) is the regulation of creditmoney to counter these developments. It sets out the need for regulating the relationship between savings and investment through interest rates policies. In the Keynesian account, the state manages economic activity through its conduct of fiscal and especially monetary policies that effect the availability of credit through the setting of interest rates, lowering them to the detriment of savings to boost investment or increasing them to prevent the economy from overheating. Keynesianism thus emphasises money as a symbol of value that is effected by the state as the political manager of capitalist labour economy. As a symbol of value, Keynesian money is state money, which in distinction to the classical tradition no longer appears as a mere instrument of exchange or standard of labour value. Rather it becomes a political tool of economic intervention.

Safeguarding the rationality of money is a major concern in economic argument. Fundamentally the debate about the security of money was about its primary function -is it primarily a means of exchange or a store of value that is held in banks until further notice? In either case, at issue is the quantity of money in circulation. If the primary function of money is as means of exchange, an increase in its quantity might lead to 
inflation as prices rise. If it is as store of value, the result of an increase in the quantity of money might result in falling interest rates and increasing economic activity. The many variations in economic argument surrounding these two positions notwithstanding, the matter resolves itself into two distinct scenarios. First there is the demand for a system "that shall be automatic" (Hicks, 1967, p. viii) in that it sets a hard monetary framework within which government conducts policy and within which the market participants adjust to price signals, neither able to assert (corrupting) influence upon the monetary conditions and therewith the conditions of the exchange of labour values. Examples of such a system include the gold standard, the Bretton Woods system and also, at least in design and purpose, the institution of central bank independence and the system of European monetary union (see Bonefeld, 2018). The advocates of a hard-money system range from David Ricardo's advocacy of a metallic system (Clarke, 1988) to Milton Friedman's demand for "a legislated rule instructing the monetary authority to achieve a specified rate of growth in the stock of money" (Friedman, 1962, p. 54). In the hard money system, public policy is confined within the limits of money.

Second, and in opposition to the first, there are demands for money to be managed by public authority to facilitate the (real) economy. Here money, credit money or Keynesian money, is regulated by government to sustain production and trade, for growth and jobs, either by easing the supply of money to prevent recession or by tightening its supply to prevent overheating. The credit-money approach entails the state in the role of an econometric technician. Its task is to sustain economic growth on an even keel. In the words of Hicks (1967, p. 167), one approach maintained "that all would be well if by some device money could be made to behave like metallic money; there was another (...) which held that credit money must be managed". It has become commonplace to associate the former with monetarism and the latter with Keynesianism. However strong the doctrinal divide, with Ricardo, Mises, Hayek, Friedman as proponents of hard money, and Mill, Thornton, and Keynes as money managers, pragmatism usually overrides principles in given economic situations. For example, Sam Brittan who had been a proponent of the monetarist hard money approach argued in response to the crash of 1987 that helicopters were needed to drop currency from the sky to stop the rot and turn the economy around (see Bonefeld, 1996). ${ }^{9}$

The economic argument about the rationality of money as a means of economic interaction is founded on the conception of a "real" economy whose activity it facilitates as a unit of account, store of value, and means of exchange, etc. Money is conceived as a mediating means of the real economy -the utility of money is that of a regulative instrument of economic activity, be it as a medium that should be put to work by government to manage pervasive economic uncertainty for the good of society

9 Looked at in this manner, financialisation appears as a means of deferring capitalist crises. See Bonefeld (1993) and Clarke (1988). See also Radice (2014). 
(Skidelsky, 2018) or as depoliticised device that functions as the representative of the invisible hand, providing an extra-political framework for the conduct of government (Friedman, 1962; Hayek, 1976). In either case, money is identified as a means of economic activity. That is, while in capitalism the purpose of economic activity is to make money out of money, to throw money into circulation for it to return with a profit (M...P...M'), economic doctrine holds that it is not an end in itself $\left(M^{\prime}\right)$ but only a means of facilitating the further development of the real economy (P...M.... $\left.P^{\prime}\right) .^{10}$

The classical Marxist argument operates with the framework of political economy. It expounded the labour theory of value of the classical tradition and explained money as the measure of the commodity labour values (see Clarke, 1988). It conceived of money as commodity money and treated it as a special labour commodity (Itoh, 1988). In this perspective, money "visualises" the commodity labour units in its function as general equivalent. According to an earlier contribution by Ricardo Bellofiore

what distinguishes [commodity money] is that, while the value of other commodities is the product of abstract labour, that is, of labour that is in the first instance private and only subsequently social, the labour that produces money is, by definition, immediately social" (Bellofiore, 1998, p. 206).

It is held to be immediately social because it is the labour that produces the general equivalent of the individual labour values of all the other commodities. The value of each individual commodity is converted into the general form of value, that is money, which functions as their universal equivalent. Money thus functions as the measure of value, means of exchange and circulation, and means of payment and also as world money, by virtue of the fact that it embodies immediately social labour. Money is able to perform these functions because it is itself a commodity -commodity-money is metallic money. Historically, gold is the foundation of commodity-money (Panceira, 2012).

The labour value of gold is the immediately social value through which the value substances of the privately produced commodities achieve universal expression as commensurable labour values. Commodity-money, gold, is thus seen as the medium into which exchange values are dipped to express their value substances. Although the classical Marxist labour theory of value expounds the labour theory of value of classical

10 According to Niall Ferguson (2018, p. iv), money is an economic enabler: "poverty is not the result of rapacious financiers exploiting the poor. It has much more to do with the lack of financial institutions, with the absence of banks, not their presence. Only when borrowers have access to efficient credit networks can they escape from the clutches of the loan sharks, and only when savers can deposit their money in reliable banks can it be channelled from the idle rich to the industrious poor". For Ferguson money is a means by which the industrious poor help themselves out of poverty. It gives them access to the liberal reward of their labour. M...P...M' stands for the formula of capital whereby money (M) is advanced to make more money ( $M$ ') by exploiting living labour in the social production process $(\mathrm{P})$. In contrast, the economic view of money as facilitator of productive activity reformulates the classical view of money as a means of buying and selling (C...M...C) into P...M...P', where money operates as a means of real economic growth, generating jobs through the expansion of real productive activity (P...P'). 
political economy, elements of its argument can indeed be found in Marx's critique, including the treatment of money as commodity-money (Heinrich, 2009). However, Marx does not expound Smith's model of an exchange economy within which independent petty producers exchange their own products, arrows and shoes, for money, which according to Ricardo, expresses a standard of wealth founded on the metallic value of gold. On the contrary, the focus of Marx's critique was Smith's model of simple reproduction, and the remains of the elements of classical political economy in Marx's account have to be judged against that critical background (Heinrich, 2009; 2017). ${ }^{11}$ Marx's work is an attempt at conceptualising the social logic of capitalist wealth, and its dynamic, through the critique of the capitalist social relations of production (Postone, 1993).

In addition to the economic function of money, the classical Marxist tradition also identifies money as an end in itself, which it defined as financial capitalism. Its contemporary form is said to be distinct from the financial capitalism analysed by Hilferding, Lenin, and Bukharin at the beginning of the last century. Unlike then it does not now amount to the dominance of banks over industry and commercial capitalism. Rather, it is held to have established money making as an independent pursuit. Financialisation is the increasing autonomy of the financial sector. It is the "increasing importance of financial markets, financial motives, financial institutions, and financial elites in the operations of the economy" (Epstein, quoted in Fontana, Pitelis \& Runde, 2019, p. 799). The proliferation of financial derivatives offers means of speculation and securization that are more profitable than productive investments. In fact, industrial and commercial capitals are now heavily implicated in financial transactions, which led to a process of displacement of capital into the financial industry. Financial capitalism also extracts financial profit directly out of the personal income of the workers, the middle classes, and in the case of Greece, a whole nation (Lapavitsas, 2018; Sawyer, 2018). These processes have also been analysed as accumulation by dispossession (Harvey, 2004).

Financial capitalism is said to have emerged from a Washington consensus between finance and military power. The consensus was reached in the early 1980s against the backdrop of a severe global recession and the subsequent emergence of the sovereign debt crisis of particularly the Latin American countries, including Mexico. ${ }^{12}$ The idea that capitalist development is the result of a consensus reached in Washington reduces financial capitalism to a conspiracy. The argument suggests that money and power reached an understanding and organised the world accordingly. In contrast to this view of the power of the (money) capitalist, and his military companion, Marx conceived of the capitalist as a personification of economic categories and saw (money) capital as a fetish-subject, which he analysed as a real abstraction that manifests itself behind

11 According to Heinrich (2017), commodity-money was the historical backdrop of his critique. It is not a conceptual necessity (Weber, 2019) and, especially since the demise of the gold standard and also the Bretton Woods system, its historical veracity has long gone.

12 For a critical reading of these events and their trajectory, see George (1991) and Soederberg (2014). 
the backs of the acting individuals. Moreover, whereas Marx had argued that there is a logic that holds sway in the concept of capital as a crisis-ridden social relationship that accumulates wealth for the sake of accumulation alone, the conspiracy theory of capitalist development holds that contemporary capitalism is in fact controlled by the money capitalists. Capitalism, as it were, behaves badly towards the many because they have taken charge. The political implication of the debate about financialisation analysis is clear. As Fontana et al. (2019, p. 799) put it, it is a "debate on how finance and financial markets and institutions might better serve the real economy and foster economic, social and environmental sustainability". The argument summarized here identifies financial capital as the irrational other of productive capital.

In conclusion, classical Marxism rejects the financial capitalism as a class project. It speaks of a neoliberal counterrevolution that transformed the real economy into a money economy. It argues for a return of "democratic control of the economy" (Callinicos, 2012; Panitch, 2019) and favours the Keynesian approach to money to bring banking and credit under public ownership and under political control so that money becomes a public utility that operates in the interests of the people rather than in the interest of the money men (see, amongst others, Blakeley, 2019; Mellor, 2019). On the one hand, classical Marxism expounds a labour theory of value and identifies money as the general equivalent of commodity labour values. Its labour theory of value is Ricardian in character. On the other, it identifies money as an independent form of wealth that in the form of financial capitalism redistributes wealth from labour to capital. Its theory of finance is Keynesian in character, both in its perception of the troublesome independence of credit money and in its proposal for the political management of that money as a symbol of value. It rejects Ricardo's hard money and bases its argument on Ricardo's labour theory of value. It recognises money making as an end in itself in financial capitalism and requires the state to make money its servant by putting it to work for growth and jobs, transforming money into an economic means of a labour economy that operates in the interest of the many. Its argument is premised on a dichotomy between labour economy and financial economy. It does not consider capitalist labour economy as a monetary system. Akin to Marx's critique of Ricardo, it "absolutely fails to grasp the connection between the determination of the exchange value of the commodity by [socially necessary] labour time, and the necessity for commodities in their development to generate money" (Marx, 1963, p. 164, translation amended). The following section explores Marx's theory of value as a monetary theory.

\section{Money as an end: on the form of value}

The understanding that capitalism is a monetary system is recent. It emerged from a literature that reads Marx's critique of political economy as a critical social theory (Arthur, 2002; Bonefeld, 2014; Clarke, 1988; Heinrich, 2017; Lotz, 2014; Pitts, 2018; 
Postone, 1993). In distinction to the classical labour theory of value, it rejects a premonetary theory of value according to which labour is the substance of value and money is the measure of that substance and its means of visualisation, exchange and circulation. In its stead, it expounds a monetary theory of value. The original impulse to this reading derived from the work of Hans-Georg Backhaus in the 1970s. Against the grain of the then established scholarship he argued that "Marx's value theory is a critique of premonetary theories of value" (Backhaus, 1975, p. 123). According to this understanding,

[v]alue has a purely social reality". It "emerges from commodity relations. Hence the universal aspect of commodities is secure only insofar as they posit it through their common relation to a universal equivalent, namely money. This money form does not represent the presupposed 'value' of commodities; rather, it presents it to them as their universal moment" (Arthur, 2005, p. 114).

The monetary theory of value holds that value is not an individual substance of a commodity. Rather, the value of a commodity is its social value. Its value is thus a property of exchangeability and money is the independent form of that property. In clarification, money is not the measure of value. This conception presupposes a premonetary existence of value. It is rather the socially valid form of measurability (see Arthur, 2005). In contrast to the labour theory of value, this or that concrete labour does not count. What counts is the social validity of this or that labour. Marx defines the socially valid labour as abstract labour (see Bonefeld, 2019). Whether this or that expenditure of concrete labour is a socially valid expenditure of abstract labour, becomes clear only post-festum in exchange for money. This section expounds money as the form of value. The comprehension of the double character of labour is central to its conception.

Marx's notion of the double character of capitalist labour is at the centre of the dispute between the pre-monetary theory of labour values and the monetary theory of value..$^{13}$ He differentiates between a concrete labour that produces use-values and an abstract labour that produces value. The dispute is about the character of abstract labour. In the traditional view abstract labour is expended in production. It is a labour that is common to all distinct concrete labours. In distinction to the concrete labour, it is an undifferentiated, homogenous labour that is characterised by the simple fact that it is expended. The proponents of a labour theory of value hold that abstract labour is the expenditure of human energy regardless of the concrete task to which it is put (Haug, 2005; Kicillof \& Starosta, 2007). Those arguing for a monetary theory of value reject the physiological explanation of abstract labour as expenditure of "nerves, muscles and brain" (Marx, 1990, p. 134; for an exposition, see Bonefeld, 2010). Instead, it holds that abstract labour is a "purely social labour" (Marx, 1990, p. 139; see Heinrich, 2009). It is not

13 See the debate between Bonefeld, Starosta, Kicillof and Carchedi in Capital \& Class, 35(2), 2011. 
expended in production. It rather manifests itself in exchange (On this, see Arthur 2001, 2004; Heinrich, 2017; Bonefeld, 2019). It does not just appear in the form of money. Rather, "money (...) is the form of existence of abstract labour" (Kay, 1979, p. 58). It is the socially necessary expenditure of concrete labour, which "appears in the form of money" (Clarke, 1988, p. 13). The distinction between the two conceptions, labour value vs. money value, could not be sharper, that is, "either money has the intrinsic 'property of being value', or money is merely a form of appearance of a value that is already immanent in all commodities (...) One cannot have it both ways" (Taylor, 2004, p. 95, citing Marx). The difficulty of the conception is well illustrated in a recent publication by Bellofiore (Forthcoming) in which he attempts to reconcile the contradictory ideas. In his view, abstract labour manifests itself in exchange. However, what manifests itself in exchange must already have been produced before it enters into circulation. He therefore posits abstract labour as valid in exchange and as latent in the immediate production process. He thus argues for a "movement" of abstract labour from the latently value producing labour in production to its social manifestation in exchange, where its value producing power is validated in the form of a certain quantity of money. In production, abstract labour produces value "in becoming", which then becomes value in being when exchanged for money. On the one hand Bellofiore argues against the premise of his own argument, trying to build a connection between production and exchange, assuming wrongly that they belong to separate realities. On the other, he depicts value as a spectre, or as a "ghost" (Bellofiore, 2009), that however fleetingly achieves value-being (Wertsein) in the form of money in exchange. This depiction is of critical importance for a monetary theory of value, and the remainder of this and the following section explore its meaning.

For Marx the two distinct qualities of capitalist labour, concrete labour and abstract labour, belong to the same labour. There is only one labour. Reality is not split into a concrete reality of material production and an abstract reality of value production. There is only one reality. Abstract labour is the valid social mode of concrete labour. Abstract labour is difficult to grasp because it is not a concrete labour. Labouring in the abstract is quite impossible. It is an invisible labour, phantom like in its objectivity and compelling in its force. It determines whether the private expenditure of social labour was productive of a social use-value, which is characterised by its exchange for money, through which it achieves social validity. Abstract labour is the labour of exchangeability. It renders the different concrete labours commensurable as equally valid expenditures of socially necessary labour. That is, abstract labour is the socially necessary expenditure of concrete labour. A product that is not exchangeable is a failed commodity. The labour that went into its production was spent unproductively and the capital that was invested into its production is sunk. Instead of producing a commodity of a certain value, devaluation strikes with potentially ruinous consequences. What cannot be exchanged for money might as well be burned or left to rot, regardless of the specific needs that its consumption might satisfy. Each individual labour process is a 
consumption process of social labour and the condition of its success as a valid expenditure of social labour expresses itself through its exchangeability with money. Whether the expenditure of concrete labour is socially required, and was thus necessary, is only known after it has been committed. The expenditure of socially unnecessary labour liquidates its employer. The expenditure of socially necessary labour is validated in the form of money.

Abstract labour is therefore the social reality of concrete labour. Against Adam Smith, Marx emphasises that it is a labour that is "forcibly brought about" by exchange (Marx, 1987, p. 299). What Marx means here by exchange is not "exchange with nature" but the exchange of commodities for money in capitalist society. Money does not express their intrinsic labour values, whatever they might be. It presents to them their social values. Value is not the substance of a single commodity. Rather, the value of a commodity is its social value. Expenditure of concrete labour is either a socially necessary expenditure and represents thus value in exchange, or it is not, in which case it does not posit any value at all, neither this value nor that value. Therefore "[w]hat makes the product a commodity is its value form" (Arthur, 2004, p. 36). Value is "something purely social" (Heinrich, 2012, p. 59). It is effected in exchange and manifests a relationship expressed in money between the labour of this commodity and the labour of all other commodities. In the form of value, the qualitatively distinct use-values vanish. What appears is money as the socially valid form of value. What matters is exchangeability for money. What counts, therefore, is money, and not just money, but the quantity of money into which the use-values are "dipped" and vanish (Cf. Marx, 1973, p. 167). The disappearance of, say, textile-producing labour into a certain quantity of money is the condition of its social validity. Its disappearance is therefore also its socially valid appearance; the social validity of textile-producing labour disappears in its appearance of, say, a 10 US dollar note. The value-validity of concrete labour posits not an atom of use-value. Rather, it posits a certain quantity of money as the value-valid expression of capitalist wealth. It is through the form of value, money, that all kinds of different concrete labours manifest an "equal social validity", which allows them to partake in "a specific social relationship" (Heinrich, 2012, p. 59), one that is characterised by cash, price and profit. Money counts and what is dipped into money achieves social validity -validity is exchangeability for money, which is commensurability between, say, cloth and bread as equal values of, say, five dollars each. Five dollars of this is the same as five dollars of that. Indeed "there is no difference or distinction in things of equal value. One hundred pounds' worth of lead or iron is of as great value as one hundred pounds worth of silver or gold" (Marx, 1990, pp. 127-28). What makes, say, apples and cars commensurable is that they represent a socially valid expenditure of social labour. As products of concrete labour they are incommensurable. The concrete labours that produced them become commensurable when they manifest themselves as products of abstract labour, which transforms them into commodities. Their socially valid appearance, which extinguishes them as apples or cars, establishes their value-being (Wertsein), which is presented to them in the form of money. 
As the socially necessary labour, abstract labour extinguishes therefore the "sensuous characteristics" of concrete labour (Marx, 1990, p. 128). In the form of value, the sensuous world assumes a ghost-walking reality as a world that "abounds with metaphysical subtleties and theological niceties" (p. 163). The metaphysical world is the money world. Whether the product of this labour or of that labour or indeed of both labours has social value and to what extent is presented to them in the form of a certain quantity of money. Nothing else expresses their value. That is, the expenditure of concrete labour either assumes the form of its opposite, that is the abstract labour of social value production, or it produces nothing at all, neither use-value nor exchangevalue. It is not the satisfaction of needs that organises the sociability of capitalist wealth. Rather, capitalist wealth comprises a sociability of money. The satisfaction of needs is merely a sideshow. What counts is money.

This section explored Marx's value theory as a monetary theory of value. It argued that "labour must directly produce exchange value, i.e., money" (Marx, 1973, p. 224). Following Clarke (1988, p. 13), the "distinctiveness of Marx theory lay[s] not so much in the idea of labour as the source of value and surplus value, as in the idea of money as the most abstract form of capitalist property". Capitalist sociability is a sociability of money. Its community is a community of money. Its system of social reproduction is a monetary system of reproduction. In this system there is no freedom from the compulsion of making money; there is however the freedom to produce money. The money-subject is the value subject.

\section{Labour and value: on money time}

The previous section argued that concrete labour does not create value. It creates social use-values, that is, use-values for others. For the expenditure of concrete labour to achieve social validity it has to generate exchange value, which is a product of abstract labour. As the socially necessary expenditure of concrete labour, abstract labour is the value producing labour. It appears in the form of money, which transforms a product of concrete labour into a commodity of a certain exchange value (Cf. Backhaus, 1997, p. 350). This section explores the expenditure of abstract labour as an expenditure of socially necessary labour time. This time, as Guy Debord put it, "has no reality apart from its exchangeability" (Debord, 1992, p. 87). It emerges as a compelling "abstraction of social time" (Bensaid, 2002, p. 75).

Expenditure of concrete labour is expenditure of concrete labour time. However, since the value of a commodity is "its social value (...) its value is not measured by the labour-time that the article costs the producer in each individual case, but by the labour time socially required for its production" (Marx, 1990, p. 434). Value equivalence is equivalence of expenditures of equally valid units of social labour time. 
Only because the labour time of the spinner and the labour time of the weaver represent universal labour time and their products are thus universal equivalents, is the social aspect of the labour of the two individuals represented for each of them by the labour of the other (Marx, 1987, p. 274).

Therefore, and as Marx put it, "labour, which is thus measured by time, does not seem, indeed, to be the labour of different subjects, but on the contrary the different working individuals seem to be mere organs of this labour" (p. 272). Just as each capital is the capital, each expenditure of socially necessary labour time is expenditure of the value-valid labour.

Each concrete labour takes place in its own good time. It has a concrete temporality. However, in order for this labour to count as a valid expenditure of social labour, it has to appear as its opposite, as an exemplar of socially necessary labour time. This labour time is independent from the concrete temporalities of the individual expenditure of labour; and yet, results "from the actions of the producers" (Postone, 1993, pp. 191 and 215). The time of abstract labour exists only through the concrete labour of definite social production processes. The establishment of socially necessary labour time is therefore an abstraction, which as such does not exist. Nevertheless, this "abstraction (...) is made on a daily basis in every social production process. The dissolution of all commodities into labour-time is no greater an abstraction, but no less real than that of all organic bodies into air" (Marx, 1987, p. 272). On the one hand, then, concrete labour is "actually expended" (Marx, 1990, p. 143) within its own time. Yet, on the other, it has to occur within a time made abstract, this is the time of socially necessary labour. Each product either "objectifies general social labour time, [which as] a specific quantity of general labour time is expressed in its exchange value" (Marx, 1987, p. 288), which transforms it into a commodity, or it does not, in which case the labour that went into it counts for nothing. In fact, it represents a loss of value. The labour time that counts is the labour time of value, which is the time of money. Value-validity is the validity of a time made abstract. Labour time is either money time or it is devalued time.

Our capitalist, this personification of "value in process, money in process, and, as such, capital", is thus spurred into action, frantically seeking to make the expenditure of concrete labour time under his command count socially as expenditure of socially necessary labour time. The individual capitalist has thus always to compare the social validity of his consumption of appropriated social labour with all other capitalists. Failure to live up to its requirements, especially through the continuous improvements in labour productivity, which reduces the socially necessary labour time of each particular commodity, is potentially ruinous. The compulsion for greater labour productivity, producing the same quantity of (social) use-values in less time, is relentless. What counts is the profitable exchangeability of the appropriated social labour time for money. How much time, then, did it take to get the commodity ready for social validation in exchange for a tidy sum of money that more than covering the costs of production yields a profit, 
too? On the pain of ruin, there really is no time to spare. The concrete labour that is not completed within the time of abstract labour is wasted, valueless, regardless of the social needs that its products might satisfy. That is, and in critique of capitalist wealth, "the labour time expended must not exceed what is necessary under the given social conditions of production" (Marx, 1990, p. 295). Time is money and money is time. If then, capitalist wealth is a function of a socially necessary labour time that as such does not exist in the concrete labour processes and that therefore is dissociated from the concrete human circumstances and purposes which it measures in terms of their social value, then, really, the time of money is everything. Indeed, in the money time of value-production, the labourer is, "at the most, a time's carcase" (Marx, 1976b, p. 127).

In distinction to a labour theory of value, which holds that the value producing abstract labour is embodied in commodities, one man's hour is not worth another man's hour of labour. Rather, on the condition that each hour of concrete labour represents an expenditure of exchangeable socially necessary labour time, "one man during an hour is worth just as much as another man during an hour" (Marx, 1976b, p. 127); or as Finelli (2007) puts it, this labouring individual is as good as any other. It is an "individual indistinguishable from all other individuals" (Marx, 1987, p. 274; translation amended), a mere resource that is employed to generate profit. Indeed, the "product is money" (Marx, 1990, p. 247). In the real community of capitalist society man "becomes the attribute of money" (Marx, 1975, p. 212). If she fails to generate money, she becomes redundant (Kotouza, 2019).

\section{Value and the "monetisation of the future"14}

Capitalist crises are not the result of political interference with the market relations and with the monetary standard of value as argued by (neo)liberal authors who consider hard money a value-requirement. Neither is money the origin of contradictions and crises as Keynesianism argues. Neither are they caused by a conflict of interest between financial and productive capital nor do they result from financialization. Neither is financial capital a parasite that sucks the living life out of productive capital. It is rather intrinsic to the capitalist social relations. Financial capitalism is therefore not a predatory version of capitalism. Instead, it manifests capitalist wealth in its most rational form. Capitalist labour is productive of social wealth on the condition that it produces value in exchange and that it thus assumes the form of money. On the pain

14 I borrowed this phrase from Lotz (2014, p. 95). David Graeber (2011) considers debt as a historical phenomenon that dates back to the emergence of human civilisation. Once debt is ontologised as a condition of human civilisation, the critique of its capitalist form appears as an unnecessary distraction in comparison with the much greater anthropological phenomena. Unsurprisingly, given the empty universalism of his argument, he holds that the organisation of the labour process in most capitalist firms is communistic in character (Graeber, 2011, p. 96). 
of ruin, what remains untouched by money represents an invalid expenditure of social labour. According to Marx, crises arise from the social nature of the commodity. ${ }^{15}$ They are innate to the conceptuality of capitalist wealth (see Clarke 1994). Indeed, the creditsystem, financial capital, establishes a form through which its crisis-ridden character can temporarily be suspended through credit-sustained growth, only to precipitate crises of great severity (Clarke, 1988, pp. 108-109). This section explores finance capital as the "elementary form" of capitalist wealth (Marx, 1973, p. 449).

In the form of finance capital, valorisation (M...P....M') "presents itself in abridged form, in its final result and without any intermediate stage, in a concise style (...) as $\mathrm{M}$ - M', i.e., money which is worth more money, value which is greater than itself" (Marx, 1990, p. 257). The "occult ability" of money to yield more money (p. 255) appears in the form of a profitable equivalence exchange relationship. ${ }^{16}$ The paradox of such an exchange appears most glaringly in the form of credit money, which posits the paradox most directly, seemingly without mediation. Exchange is either an exchange between equivalent values or it is not an equivalent exchange. Marx argues that in bourgeois society it is both and he explains it with reference to the difference between the value of labour power and the total value produced by the consumption of labour during the working day. The prerequisite is the existence of the doubly free labourer. He establishes the trade between the owner of the means of production, whom he nicknames "moneybags" in chapter 6 of Capital and whom he characterises as having a werewolf's hunger for labour time in chapter 10, and the free labourer as an equivalence exchange according to which the commodity labour power is exchanged at its value, which is the socially necessary labour time required for its (re)production. At its best, the exchange relationship is one between equal legal subjects who trade in labour power according to the rules of the game, the one for the sake of making a profit to avoid bankruptcy through the valorisation of labour, the other to dodge the "freedom to starve" (Adorno, 2008, p. 201) through wage income. Valorisation entails a process by with the consumption of living labour reproduces the value of labour power and produces new values, which he calls surplus value, during the social working day. Marx follows the dispossessed labourer, who has relinquished her commodity labour power to its buyer who by virtue of having purchased it has acquired the right to consume it during the working day, into the hidden abode of production to examine the processes by which "moneybags" changes into an insatiable werewolf of labour time, consuming labour for profit. Money yields more money because "moneybags" invests money in a commodity, labour power, whose consumption produces a surplus value. The original outlay returns to moneybags with a surplus. The resolution to the conundrum of a

15 As Marx (1973, p. 147) put it, the "contradiction between the commodity's natural qualities and its general social qualities contains from the beginning the possibility that these two separated forms in which the commodity exists are not convertible into one another".

16 On the apparent paradox of a profitable equivalent exchange, see Bonefeld (2016). See also O'Kane's (2018) introduction to Adorno, Erlenbusch-Anderson \& O’Kane (2018). 
profitable equivalent exchange of money for more money rests on the concept of surplus value.

In the form of interest, the insight that "money is labour time in the form of a general object" (Marx, 1973, p. 168) is not immediately recognisable. In fact, the social character of labour vanishes in the money existence of the commodities, and even more so in credit-money. In this form capital becomes a commodity, which is sold for its ability to yield a profit in the form of interest. Interest obscures the actual social relations of production. Wages seem to accrue to labour, profit to capital, and interest to finance. These distinct sources of wealth manifest themselves as a process of social reproduction from which all connections to the valorisation of living labour, the surplus value extraction, which is the means of money making, are eliminated. Although the financial earnings represent a claim on surplus value, in its "abridged" form, M...M', "all connections vanish" (Marx, 1966, p. 823) and what remains is the seemingly "transcendental power of money" (Marx, 1973, p. 146) that presents itself as the source of its own self-expansion. Indeed, profit and interest appear "as though they generate from essentially different sources" (Marx, 1966, p. 375). In the credit form, the processes of valorisation appear not only unmediated, "unassisted" by actual labouring for profit, they also appear in the form of a distinction between productive capital and financial capital. What appears in this distinction is a false separation. That is, "the whole capitalist dynamic is monetary in form" (Nelson, 2011, p. 28) and if the critique of finance capital is not to become a piece of the criticised political economy, it is fundamentally a critique of the capitalist mode of production.

It is indeed the case that no sooner as money making "is transformed into 'capitalinterest"' (Marx, 1966, p. 823) money appears to dissociate itself from the valorisation of living labour and instead it appears to posit itself as an autonomous form of wealth. Finance capital sells money, gambles by putting down wagers, exploits currency differentials, securitizes the social relations, and hedges its bets on potential outcomes, whatever they might be. Finance capital is the "simple form of capital" (p. 392). It accumulates wealth akin to a Ponzi scheme that glitters with great promise until the fall, when, as in 2008, suddenly and without warning, it reveals its promise as a fiction, with bankrupting consequences.

Financial capital appears as parasitic whereas in actual fact it subordinates every individual capitalist, and workers too (Bonefeld, 2014), to the immanent laws of capitalist production, according to which money has to posit more money on an expanding scale. Its wealth is "value in process, money in process, and, as such, capital (...) M...M', money which begets money" (Marx, 1992, p. 256). Capital is a social relationship of the valorisation of value through the exploitation of labour. Its social validity appears in the form of money. In the form of finance, valorisation appears as a securitized social relationship. On the one hand, its financial property entails a promissory note on the extraction of future surplus value. It represents a "claim of ownership upon labour" (Marx, 1966, p. 476) as "interest is only a portion of the profit, i.e., of the surplus value, 
which the functioning capitalist squeezes out of the labourer" (p. 392). On the other, it "antecedes its own reproduction" (p. 392) by mortgaging the future valorisation of living labour. The security of this mortgage, which can itself be securitized, is dependent upon the servicing of the accumulating claims upon labour through the profitable extraction of capital-interest in the present. The viability of mortgaged wealth rests on the valorisation of living labour in the present, which is assessed for its effectiveness in delivering greater profitability by the financial markets. The security of the monetised future is the contemporary extraction of surplus value. The monetised future is founded on the effective exploitation of labour in the present, to prevent bad debt and default. In the meantime, moneybags hedges his bets. Financial markets really do hedge their bets on the future profitability of labour in the present, and in so doing they impose the immanent law of value as a seemingly external coercive force upon the acting individuals. ${ }^{17}$

And when the receiver is called in, "credit no longer resolves the value of money into money but into human flesh and the human heart." That is, man is turned

into money, or money is incorporated in him. Human individuality, human morality itself, has become both an object of commerce and the material in which money exists. Instead of money, or paper, it is my own personal existence, my flesh and blood, my social virtues and importance, which constituted the material, corporeal form of the spirit of money (Marx, 1975, p. 215).

I have argued that moneybags buys the labour power of the dispossessed so that they "produce [more] money", which is the means also for sustaining financial profit. Financialisation is the abridged version and unmediated manifestation of the money subject. It securitises uncertainty, mortgages the future extraction of surplus value, takes money from the pockets of the dispossessed, socialises the losses through a politics of austerity, and dazzles to deceive. Debt bondage in the present "securitises" the monetised future.

\section{Conclusion}

The paper explored money as the social form of capitalist wealth. I argued that money is not a conventional means of organising the so-called "real economy". Rather, the purpose of the "real economy" is to produce money for the sake of more money. Understood in this precise manner, the "real economy" is a means of money-making. Money is a depersonalised and anonymous social power that both confines capitalist production to the limits of its form and that, in the form of capital-credit, stretches

17 For a thorough elaboration in the context of the crisis of 2008, see Sotiropoulos, Milios and Lapastsrioras (2013). See also the contributions to the volume edited by Bonefeld and Holloway (1995). 
this limit by mortgaging the future generation of capitalist wealth. Following Clarke (1988, p. 9), although monetarism and Keynesianism articulate the concept of money in ideological terms as either a standard of wealth or a symbol of wealth, they contain within themselves, and however mystified in their articulation, the practical truth of money as the "embodiment" of capitalist wealth. Capitalist wealth comprises a "community of money" (Marx, 1973, p. 225).

In the case of the debate about financial capitalism, it contains the practical truth that money-making is the elementary form of credit-money as a seemingly independent form of value. I have argued that credit-money stretches the limits of capitalist wealth and it is indeed the case also that this wealth is enforced upon the dispossessed sellers of labour power in the manner analysed by the debate about financial capitalism. However, by contrasting finance capital and productive capital as separate identities the debate about financialisation dissolves the conceptuality of capitalist wealth into an argument about the financial wealth and the productive wealth as seemingly distinct categories. It condemns the excesses of the former and argues on behalf of the latter. The debate about financialisation therefore reinforces the fetish of the money subject and fetishizes the real economy. My account expounded the "real economy" as a monetary economy. That is, "the riddle of the money fetish is (...) the riddle of the commodity fetish" (Marx, 1990, p. 187). Finance and production are conceptually bound. The capital fetish is the money fetish.

The paper expounded Marx's value theory as a monetary theory of value. I argued that labour is the means of valorisation and that money is the form which expresses, or denies, the value-validity of its effort. That is, value is not established before or independently from the value form. Money is the existent form of abstract labour, which is the socially valid expenditure of concrete labour. Value is effected in exchange for money. There can be no value without the value form. Money is the form of value. I therefore argued that money does not represent the "embodied", or "latent" (Bellofiore, Forthcoming), value of commodities in a visible form. Rather, money "presents it [value] to them as their universal moment" (Arthur, 2005, pp. 114 and 123). I argued that the value-validity of concrete labour is the validity of a time made abstract. Labour time is either money time or it is devalued time. On the pain of ruin, what counts is money -as more money. Whether money is Keynesian money or hard money, it "processes wealth" by sustaining bourgeois society as a community of money.

In conclusion, I have argued that money is not a means of the commodity exchange relations and that finance is not a perversion of that means. Money is rather "a representative of the socially valid character of wealth" (Campbell, 2004, p. 85) and finance is the bewitching form of that wealth. It does not recognise hardship, nor does it know the right to housing, welfare, education, and human dignity (see Bologna, 1993). However, the money subject does not create the coldness of capitalist society. It represents it and, as such, it presents it to the social actors, requiring them to generate more money in order to sustain the strength of their link to 
the "world of social wealth" (Marx, 1990, p. 739). It is a truly abstract power. Leaving aside its dazzling wizardry, Man (Mensch) does not eat money. However, in capitalism without money she does not eat.

\section{References}

Adorno, T.W. (2008). Lectures on History and Freedom. Cambridge: Polity.

Adorno, T. W., Erlenbusch-Anderson, V., \& O'Kane, C. (2018). Theodor W. Adorno on Marx and the Basic Concepts of Sociological Theory. Historical Materialism, 26(1), 154-164. https://doi.org/10.1163/1569206X-00001619

Arthur, C. (2001). Value, Labour, Negativity. Capital \& Class, 25(1), 14-39. https://doi.org/10.1177/030981680107300103

Arthur, C. (2002). The New Dialectic and Marx's Capital. Leiden: Brill.

Arthur, C. (2004). Money and the Form of Value. In Bellofiore, R. \& Taylor, N. (eds.), The Constitution of Capital: Essays on Volume 1 of Marx's Capital (pp. 35-62). London: Palgrave. https://doi.org/10.1057/9781403938640_2

Arthur, C. (2005). Value and Money. In Moseley, F. (ed.), Marx's Theory of Money (pp. 111-123). London: Palgrave. https://doi.org/10.1057/9780230523999_8

Backhaus, H. G. (1975). Materialien zur Reconstruktion der Marxschen Werttheorie 2. In Gesellschaft. Beiträge zur Marxschen Theorie 3 (pp. 122-159). Frankfurt: Suhrkamp.

Backhaus, H. G. (1997). Die Dialektik der Wertform. Freiburg: Ca-ira.

Bellofiore R (1998). Marx's theory of money and Credit Revisited: A Comment on the Chapters by Suzanne de Brunhoff and Ferdinando Meacci. In Bellofiore R (ed.), Marxian Economics: A Reappraisal, vol. I (pp. 205-215). London: Plagrave. https://doi.org/10.1007/978-1-349-26121-5

Bellofiore, R. (2009). A ghost turning into a vampire. In Bellofiore R and Fineschi R (eds.), Re-reading Marx (pp. 178-194). London: Palgrave. https://doi.org/10.1007/978-0-230-30514-4_11

Bellofiore, R. (Forthcoming). Isaak Ilijč Rubin: fetishism, the form of value, and abstract labor. In Kouvelakis, S., Callinicos, A., \& Pradella, L. (eds.), Handbook of Marxism and Postmarxism. London: Routledge.

Bensaid, D. (2002). Marx For Our Time. London: Verso.

Blakeley, G. (2019). Stolen. How to Save the World from Financialisation. London: Repeater Books.

Bologna, S. (1993). Money and Crisis. Common Sense, 13 \& 14 :

https://commonsensejournal.org.uk/tag/sergio-bologna/

Bonefeld, W. (1993). The Recomposition of the British State. Aldershot: Dartmouth.

Bonefeld, W. (1996). Monetarism and Crisis. In Bonefeld, W. \& Holloway, J. (eds.), Global Capital, National State and the Politics of Money (pp. 35-68). London: Palgrave. https://doi.org/10.1007/978-1-349-14240-8_3 
Bonefeld, W. (2010). Abstract Labour: Against its Nature and on its Time. Capital \& Class, 34(2), 257-76. https://doi.org/10.1177/0309816810367769

Bonefeld, W. (2014). Critical Theory and the Critique of Political Economy. London: Bloomsbury.

Bonefeld, W. (2016). Negative Dialectics and the critique of economic objectivity. History of the Human Sciences, 29(2), 60-76. https://doi.org/10.1177/0952695116637294

Bonefeld, W. (2018). Stateless Money and State Power. History of Economic Thought and Policy, 2018/1, 5-26. https://doi.org/10.3280/SPE2018-001001

Bonefeld, W. (2019). Abstract Labour and Labouring. In Bellofiore, R. \& Fanbiana, C. M. (eds.), Marx Inattuale (pp. 207-225). Rome: Edizion Efesto.

Bonefeld, W. \& Holloway, J. (eds.). (1996). Global Capital, National State and the Politics of Money. London: Palgrave. https://doi.org/10.1007/978-1-349-14240-8

Caffentzis, G. (1989). Clipped Coins - Abused Words and Civil Government: John Locke's Philosophy of Money. New York: Autonomedia.

Campbell, M. (2004). 'The Objectivity of Value versus the Idea of Habitual Action'. In Bellofiore, R. \& Taylor, N. (eds.), The Constitution of Capital: Essays on Volume I of Marx's Capital (pp. 63-87). London: Palgrave. https://doi.org/10.1057/9781403938640_3

Clarke, S. (1988). Keynesianism, Monetarism and the Crisis of the State. Aldershot: Edward \& Elgar.

Clarke, S. (1992). Marx, Marginalism and Modern Sociology. London: Palgrave. https://doi.org/10.1007/978-1-349-21808-0

Clarke, S. (1994). Marx's Theory of Crisis. London: Palgrave. https://doi.org/10.1007/978-1-349-23186-7

Cleaver, H. (1995). The Subversion of Money-as-Command in the Current Crisis. In Bonefeld, W. \& Holloway, J. (eds.), Global Capital, National State and the Politics of Money (pp. 141-177). London: Palgrave. https://doi.org/10.1007/978-1-349-14240-8_7

Debord, G. (1992). Society of the Spectacle. London: Rebel Press.

Driffiill, J. \& Stiglitz, J. E. (2000). Economics. London \& New York: Norton.

Ferguson, N. (2018). The Ascent of Money: The Financial History of the World. London: Penguin.

Finelli, R. (2007). 'Abstraction versus Contradiction'. Historical Materialism, 15(2): 61-74. https://doi.org/10.1163/156920607X192075

Fontana, G., Pitelis, C. \& Runde, J. (2019). Financialisation and the new capitalism? Cambridge Journal of Economics, 43, 799-804. https://doi.org/10.1093/cje/bez029

Friedman, M. (1962). Capitalism and Freedom. Chicago: University of Chicago Press.

George, S. (1991). The Debt Boomerang. London: Pluto.

Graeber, D. (2011). Debt. The first 5000 years. New York: Melville.

Harvey, D. (2004). The New Imperialism. Oxford: Oxford University Press.

Haug, W, F. (2005). Vorlesungen zur Einführung ins Kapital. Hamburg: Argument. 
Hayek, F. (1976). Denationalisation of Money. London: Institute of Economic Affairs.

Heinrich, M. (2009). Reconstruction or Deconstruction. In Bellofiore, R. \& Fineschi, R. (eds.), Rereading Marx (pp. 71-98). London: Palgrave.

Heinrich, H. (2012). Introduction to the Three Volumes of Capital. New York: Monthly Review Press.

Heinrich, H. (2017). Die Wissenschaft vom Wert. Münster: Westfälisches Dampfboot.

Hicks, J. (1967). Critical Essays in Monetary Theory. Oxford: Clarendon Press.

Itoh, M. (1988). The Basic Theory of Capitalism. London: Macmillan. https://doi.org/10.1007/978-1-349-19107-9

Kay, G. (1979). Why Labour is the starting point of Capital. In Elson, D. (ed.), Value: The Representation of Labour in Capitalism (pp. 46-66). London: CSE Books.

Keynes, J. M. (2017). The General Theory of Employment, Interest, and Money. London: Wordsworth Editions. https://doi.org/10.1007/978-3-319-70344-2

Kicillof, A. \& Starosta, G. (2007). 'On Materiality and Social Form'. Historical Materialism, 15(3), 9-43. https://doi.org/10.1163/156920607X225852

Kotouza, D. (2019). Surplus Citizens. London: Pluto. https://doi.org/10.2307/j.ctvjnrt95

Lapavitsas, C. (ed). (2012). Financialisation in Crisis. Leiden: Brill. https://doi.org/10.1163/9789004201088

Lapavitsas, C. (2018). The Left Case Against the EU. Cambridge: Polity.

Lotz, C. (2014). The Capitalist Schema. London: Lexington Books.

Marx, K. (1963). Theories of Surplus Value, Part 2. London: Lawrence \& Wishart.

Marx, K. (1966). Capital, Vol. 3. London: Lawrence \& Wishart.

Marx, K. (1973). Grundrisse. London: Penguin.

Marx, K. (1975). Comments on James Mills. Collected Works, vol. 3. London: Lawrence \& Wishart.

Marx, K. (1976a). Theorien über den Mehrwert. MECW 26.3. Berlin: Dietz.

Marx, K. (1976b). The Poverty of Philosophy. MECW 6. London: Lawrence \& Wishart.

Marx, K. (1987). Contribution Toward a Critique of Political Economy. In MECW 29. London: Lawrence \& Wishart.

Marx, K. (1990). Capital, Vol. 1. London: Penguin.

Mellor, M. (2019). Money. Bristol: Policy Press. https://doi.org/10.2307/j.ctvk3gkt7

Negri, T. (1984). Marx Beyond Marx. Cambridge, MA.: Bergin \& Garving.

Nelson, A. (2011). Money versus Socialism. In Nelson, A. \& Timmerman, F. (eds.), Life Without Money: Building Fair and Sustainable Economies (pp. 23-46). London: Pluto. https://doi.org/10.2307/j.ctt183p6xc.7

O'Kane, C. (2018). Introduction to Theodor W. Adorno on "Marx and the Basic Concepts of Sociological Theory". From a Seminar Transcript in the Summer Semester of 1962. Historial Materialism, 26(1), 137-153. https://doi.org/10.1163/1569206X-00001618 
Painceira, J. P. (2012). Developing Countries in the Era of Financialisation: From DeficitAccumulation to Reserve-Accumulation (pp. 185-216). London: Soas University. https://doi.org/10.1163/9789004201088_009

Panitch. L. (2019). 'Ralph Miliband's Masterpiece at 50'. Jacobin. https://www.jacobinmag.com/2019/06/ralph-miliband-state-capitalist-society

Pitts, F. H. (2018). Critiquing Capitalism Today. London: Palgrave. https://doi.org/10.1007/978-3-319-62633-8

Postone, M. (1993). Time, Labour and Social Domination. Cambridge: Cambridge University Press. https://doi.org/10.1017/CBO9780511570926

Radice, H. (2014). Global Capitalism. London: Routledge.

Reichelt, H. (2008). Die neue Marx Lektüre. Hamburg: VSA.

Ricardo, D. (1951). On the Principles of Political Economy and Taxation. Cambridge: Cambridge University Press.

Sawyer, M. (2018). The Power of Finance. Financialisation and the Real Economy. Newcastle upon Tyne: Agenda.

Skidelsky, R. (2018). Money and Government. London: Allen Lange. https://doi.org/10.2307/j.ctv6gqq16

Smith, A. (1976). The Wealth of Nations. Oxford: Oxford University Press.

Smith, T. (2005). Globalisation: A Systematic Account. Leiden: Brill.

Soederberg, S. (2014). Debtfare States and the Poverty Industry. London: Routledge. https://doi.org/10.4324/9781315761954

Sotiropoulos, D. P., Milios, J. \& Lapastsrioras, S. (2013). A Political Economy of Contemporary Capitalism and its Crises. London: Routledge. https://doi.org/10.4324/9780203771297

Taylor, N. (2004). 'Reconstructing Marx on Money and the Measurement of Value'. In Bellofiore, R. \& Taylor, N. (eds.), The Constitution of Capital: Essays on Volume 1 of Marx's Capital (pp. 88-116). London: Palgrave. https://doi.org/10.1057/9781403938640_4

Weber, I. (2019). 'On the Necessity of Money in an exchange-constituted economy'. Cambridge Journal of Economics, 43(6), 1459-1483. https://doi.org/10.1093/cje/bez038 